\title{
CONCEPTIONS AND PERCEPTIONS OF STUDENT INITIATIVE HELD BY ELEMENTARY SCHOOL TEACHERS AND STUDENTS²
}

\begin{abstract}
The aim of this study is to provide empirical analysis of teachers' and students' understanding of the term student initiative and their perceptions of its manifestations in school environment. A total of 182 teachers and $2238^{\text {th }}$ grade students were asked to (1) provide associations to the term "initiative", (2) to specify personal characteristics and behaviors of students with high initiative and (3) to report on the importance and levels of student initiative manifested in different domains of school functioning. Both teachers' and students' associative fields for the term initiative are extremely large and with weak associative strength, implying various diverse meanings. However, both groups consider student initiative as an important feature for school functioning and report on student initiative being manifested in different domains of school life. While there are some differences, both groups connect student initiative with success in school but not with the gender of the student, pointing out prosocial behavior in the school environment and dedication to learning, as well as readiness for additional engagement in the class. Implications for school practice are discussed in terms of changing teacherstudent patterns of conversational activities and inclusion of complex and challenging tasks connected to learning material.
\end{abstract}

Keywords: student initiative, elementary school, teacher's perspective, student's perspective presenting material in school.

\section{Introduction}

The paper focuses on the concept of student initiative that has been introduced from the field of educational policy into the discourse of contemporary science of education. The sense of initiative and entrepreneurship, as an ability to transform ideas into actions,

1 E-mail: npolovina@ipi.ac.rs

2 The article is the result of the project From Encouraging Initiative, Cooperation and Creativity in Education to New Roles and Identities in Society (No. 179034) and Improving the Quality and Accessibility of Education in Modernization Processes in Serbia (No. 47008), financially supported by the Ministry of Education, Science and Technological development of the Republic of Serbia (2011-2015). 
to plan and direct actions toward an established goal, is postulated as one of five crosscurricular competences which needs to be developed in the elementary school and beyond (Halász \& Michel, 2011; Peterman \& Kennedy, 2003). The importance of researching the phenomenon of student initiative is elaborated in relation to: the quality of teaching and learning (use of inquiry practices in classroom); the student's engagement and motivational processes associated with acquisition of high-quality and applicable knowledge, the preparation of the student for effective participation in the increasingly demanding labor market (Axelson \& Flick, 2010; Danielsen et al., 2010; Larson, 2000).

However, there is a discrepancy between the call in policy documents for the recognition of the concept student initiative and the current state of theory, research and practice in this subject area. This discrepancy is not surprising if we take into account the novelty of the implied approach to student learning and behavior, the difficulty of defining the concept of student initiative and the extensive use of the similar but theoretically and empirically better grounded concepts of student engagement and student participation (Appleton et al., 2008; Fredricks et al., 2004; Michel \& Tiana, 2011). Similarities and differences of these three concepts were addressed in details by Polovina (2014). While both student initiative and student participation refer to the willingness of the student to participate in academic and non-academic activities in school environment, the concept student participation is associated with the development of democratic school climate including students participation in decision-making - the issue not associated with the concept of student initiative. Polovina stresses that both student engagement and student initiative are elements of motivational processes related to learning - they differ in that student initiative implies action, enthusiasm and potentially creative / innovative orientation towards future, while student engagement implies persistence in concentration to the existing program activities.

\section{Previous Conceptualizations and Research}

In the small number of papers that address the phenomenon of student initiative there is no consensus regarding either the terminology or the conceptualisations. However, the current conceptualizations, mainly research-generated, can be grouped into those that specify the concept student initiative in the field of education (Lewis et al., 2010; Llorent, 2012; Stevens \& Miretzky, 2012; Wade, 1995) and those that specify the concept in the broader field of young person development (Larson, 2000; Robitschek \& Cook, 1999).

Wade (1995) uses the term student initiative to denote the following student activities: making choices (among proposed or self-initiated materials) and decisions in the process of learning, launching, planning and implementing of their own "projects", expressing autonomy and advocacy of their ideas in communication with their teachers. Lewis and her collaborators (2010) specify the term student initiative as the student's activity of posing questions or giving unprovoked comments regarding the presented subject matter. Stevens and Miretzky (2012) use the term student's academic initiative to denote one aspect of the frame of reference through which teachers perceive student behavior their interest in a specific subject, effort to prepare for class and readiness to grapple with complicated ideas. Llorent (2012) uses the term individual initiative to denote tolerance 
of uncertainty and risk, learning from mistakes, development of management skills - all important for the later development of an orientation toward entrepreneurial behavior. Larson (2000) uses the term development of capacity for initiative to denote motivation from within, directing attention and effort toward challenging goals, social competence, compassion and psychological forcefulness - all important for young persons' current functioning and for their positive development into adulthood. Robitschek (1998, p.184) uses the term personal growth initiative and defines it as the "active, intentional engagement in the process of personal growth". Despite the differences, in almost all the abovementioned conceptions of student initiative, the notion of personal interest, self-initiated, self-directed exploration and planning actions toward a challenging goal is central.

A few studies have already explored aspects of student initiative in the school context focusing on the teacher's role and perspective. Findings indicate that: teachers perceive student initiative as important, age-unspecific behavior manifested in different domains of student school functioning (Komlenović i Polovina, 2012); when the teacher recognizes a student as showing initiative, the perception of the student's knowledge and skills increases (Stevens \& Miretzky, 2012); when the teacher creates a classroom environment that empowers students (classroom democracy, work on projects), students will initiate their own learning in a variety of ways (Wade, 1995). Few studies have focused on the student perspective and behavior. Lewis and her collaborators (2010) explored student initiative in an observation study of 70 elementary school classes, estimating the quality of student initiative by three types of questions students posed: procedural (refer to procedure of learning), factual (related to factual content of the lesson), conceptual (refer to clarifying, elaborating and/or questioning concepts in learning material). The findings of this study indicate that the frequency as well as the quality of student initiative was low. According to the assessments of thirteen-year old students, academic student initiative varies according to school grade and the teacher's fairness, friendly approach and support for the student's autonomy (Danielsen et al., 2010).

The studies presented offer important initial elements for mapping the "territory" of the student initiative concept from the perspective of teachers and the perspective of students. Not surprisingly, both "sides" stress the importance of creating classroom and school environments that support the expression of student initiative, above all the importance of the quality of the teacher - student relationship - a topic that occupies the most prominent position among school-related factors important for the quality of teaching and learning (Hargreaves, 2000; Hattie \& Timperley, 2007; Urdan \& Schoenfelder, 2006). Looking back briefly into the main research issues concerning the nature and quality of teacher-student interrelationship indicate that much attention was directed to the teacher's beliefs and their behavior, less attention was paid to the indirect messages (grounded in implicit social cognition, automatically activated) that teachers convey to students which have an effect on students' self-perceptions and motivations (Christensen \& Menzel, 1998; Witt \& Wheeless, 2001).

Also, the topic of differences between teachers' and students' perceptions, comprehensions and expectations concerning different aspects of school functioning is insufficiently recognized (Weber \& Mayer, 2011). In this regard, there is a need for studies that 
examine both students' and teachers' conceptions and perceptions around the same issue of school functioning. Generally speaking, since teachers are expected to encourage student initiative, it is important to know to which extent they are determined to tackle this phenomenon. When it comes to students, in order to support their initiative effectively, it is important to know the initial point from which to start. In that respect, in our study we aimed to explore (1) how students and teachers understand the term initiative and the concept of student initiative - which attributes are central in their descriptions; (2) to what extent students and teachers attach importance to the expression of student initiative in the school environment; (3) are there any differences in students' and teachers' perceptions of the expressions of student initiative in different domains of school functioning; (4) to what degree the understanding of students and teachers are related or unrelated.

\section{Method}

\section{Participants}

The research was carried out with a convenient sample of elementary school teachers and students from the Serbian capital and four other towns. The teacher sample included 182 class and subject teachers (16\% male and $84 \%$ female). The average age of the teacher participants was 43.81 years $(S D=9.56)$, and the average length of years in service in the educational system was 16.11 years $(S D=9.85)$. There were $2238^{\text {th }}$ grade student participants (51.6\% male and $48.4 \%$ female). The average age of participating students was 13.91 years $(\mathrm{SD}=0.29)$.

\section{Instrument and procedure}

A research-developed questionnaire in two parallel versions (teacher and student version) was used. Both versions of the questionnaire had three parts that were physically separated and completed successively in the following order: (1) questions about basic socio-demographic variables - gender, age, years of service in the educational system, (2) semantic word association task, (3) self-reported questionnaires.

Semantic word association task. The free word association task was used as a technique suitable for the assessment of mental content and implicit cognition that underlie perception and meaning. In addition to its already consolidating scientific use (De Deyna et al., 2009; Zortea \& de Salles, 2012) and offered frame (Nelson et al., 2000) for data analysis (standard measures: forward associative strength, meaning set size, and total set size measures), the choice of this technique was inspired by Larson's assumption (2000) that the study of language use is a promising approach to the investigation of the concept of initiative since it reflects the day-to-day functioning of a student. For the purposes of our research we designed a simple form of association task that can be applied within the paper-pencil set of instruments, and given the differences in the age of two groups of participants. The task included the term initiative as the target stimuli and the multiple 
response procedure - respondents were asked to list and to write down the first five associations that came to his/her mind with the meaning related to the term initiative.

Self-reported questionnaires. Questionnaires for students and teachers aimed at eliciting the respondents' explicit attitudes toward the target concept of student initiative. Students and teachers were asked: (1) to estimate the importance of student initiative in the school environment (given on the 10-point Likert-type scale, ranging from not important at all /1/ to extremely important /10/); (2) to estimate to what extent (on a scale of $0 \%$ to $100 \%)$ students express their initiative in five domains of school functioning: learning in the classroom, extra-curricular activities, peer relations, relations between teachers and students, regulation of disciplinary issues; (3) to report on the general background information (age, gender and academic achievement), personal characteristics and behaviors of students/peers whom they perceive as exhibiting the most initiative in the school environment. Since the last question was a complex open-ended question (Please describe the typical behavior and characteristics of one of your students/school mates whom you consider to show the most initiative in school in comparison with other students), a wide range of descriptions covering personal and behavioral characteristics was collected from the participants ${ }^{3}$ and analyzed separately using qualitative content analysis.

The students' and teachers' versions of questionnaires differed in one aspect. During the pilot examination of the free word associations task on the students' sample (a convenient sample of 30 students), after giving associations to the term "initiative" half of them conveyed their insufficient understanding of the meaning of the term initiative. Therefore, in the main survey, on the front page of the students' version of the self-report questionnaire the elementary definition of the term initiative around which there is agreement in the Serbian language (Vujanić i dr., 2011) was given: "A person who takes initiative is one who independently, without support or incentives from others, engages in certain activities in order to achieve certain goals".

Confidential questionnaires were distributed through a teachers' representative at each school to teachers who agreed to participate in the study. The teachers filled in the questionnaires individually. The students filled in the questionnaires in groups, in paper or electronic form, under the supervision of teachers and researchers. The questionnaires were given only to those students who willingly agreed to participate. The teacher survey took place during the second half of 2011, whereas the student sample was surveyed during the second half of 2012.

\section{Data analysis}

Viewed as a whole, the data were analyzed by quantitative techniques. Besides calculating basic descriptive indicators and the analysis of frequency, quantitative techniques for comparison of frequencies (hi-square test) and means (ANOVA) were applied.

The data obtained on the associative field of the term initiative were analysed including three standard measures introduced by Nelson, McEvoy and Dennis (2000). All

3 Ten participants in the teachers' sample and twenty-seven in students' sample did not answer this question. 
three measures were calculated by frequency analysis. The first one is the total set size, and it indicates the total number of associations provided by the participants. The second measure, the meaning set size, refers to the total number of different associations and it is the measure of the size of the associative field. The associative field is considered small if participants state up to 8 different meaning, medium in size if its meaning set size is between 9 and 16, while large associative fields include more than 17 different meanings. The third measure is forward associative strength, which represents the percentage of participants who stated the most frequent response. If less than $10 \%$ of participants gave the most frequent association, the associative field is considered weak. The field is of medium strength if the measure of the forward associative strength varies between 10 and $24 \%$, and if more than $25 \%$ of participants give the most frequent association, the associative field is considered strong.

For the narrative part of answers to the open-ended question concerning descriptions of personal characteristics and behaviors analytical technique of content analysis was applied with a purpose of classifying and quantifying the data, and producing simple report of common issues mentioned in the data that reflects understanding of the phenomenon of student initiative from the perspective of participants' experience (Forman \& Damschroder, 2008). The strategy we used to analyze text-answers had both deductive component (using categories typical behavior and characteristics given in the instruction for classifying units of content) and inductive component of the theoretical approach concerning characteristics or behaviors as the bias for informational content of the data)

\section{Results}

\section{Teachers' and students' understanding of the term initiative}

Although the students provided a somewhat larger number of different meanings when associations of the term initiative were elicited (310 compared to 243 in teachers' sample), the data in Table 1 indicate that the associative field of the term initiative can be considered as extremely large in both samples. As expected, the diversity of associated words/phrases is higher among students than teachers. This finding reflects the fact that the teachers used words that can be grouped according to semantic similarities more frequently than the students did. Although the forward associative strength of the students' associative field is slightly higher (8.08\%) than the teachers', in both cases we are dealing with a weak associative field. This is illustrated by the data in Table 2, which shows the frequency of the ten most frequently used words/phrases that the teachers and students stated as associations of the term initiative. The common semantic core of teachers' and students' associations consists of the following words: idea, wish/will, activity, work, incentive, motivation. This common associative core indicates that to some extent students and teachers share an understanding of initiative as a conscious and willing initiation of certain activities - understanding which is on the generally accepted, colloquial level. In addition, teachers' stressed enterprise and creativity, while students' stressed goals and persistence. 
Table 1. Characteristics of the associative field of the term initiative in teachers' and students' sample

\begin{tabular}{lll}
\hline & \multicolumn{2}{c}{ Term Initiative } \\
\cline { 2 - 3 } & Teachers & Students \\
\hline Total set size & 803 words & 780 words \\
Meaning set size & 243 different words & 310 different words \\
Forward associative strength & $5.08 \%$ & $8.08 \%$ \\
\hline
\end{tabular}

Table 2. Students' and teachers' associations to the term initiative

\begin{tabular}{|c|c|c|c|c|c|c|}
\hline \multicolumn{7}{|c|}{ Term Initiative } \\
\hline \multicolumn{3}{|c|}{ Teachers } & \multicolumn{4}{|c|}{ Students } \\
\hline & Associations & $f$ & $\%$ & Associations & $f$ & $\%$ \\
\hline 1 & Enterprising & 40 & $5.08 \%$ & Wish/Will & 63 & $8.08 \%$ \\
\hline 2 & Idea & 35 & $4.44 \%$ & Goal & 31 & $3.97 \%$ \\
\hline 3 & Initiating/Movement & 35 & $4.44 \%$ & Persistence & 26 & $3.33 \%$ \\
\hline 4 & Incentive & 32 & $4.06 \%$ & Work & 19 & $2.43 \%$ \\
\hline 5 & Creativity & 25 & $3.17 \%$ & Success & 15 & $1.92 \%$ \\
\hline 6 & Activity & 24 & $3.04 \%$ & Trying & 14 & $1.79 \%$ \\
\hline 7 & Will/Wish & 23 & $2.92 \%$ & Activity & 26 & $3.33 \%$ \\
\hline 8 & Motivation & 17 & $2.16 \%$ & Motivation & 11 & $1.41 \%$ \\
\hline 9 & Work & 16 & $2.03 \%$ & Idea & 11 & $1.41 \%$ \\
\hline \multirow[t]{3}{*}{10} & Progress & 15 & $1.90 \%$ & Incentive & 18 & $2.31 \%$ \\
\hline & Other & 541 & $66.73 \%$ & Other & 546 & $70.66 \%$ \\
\hline & Total & 803 & $100 \%$ & & 780 & $100 \%$ \\
\hline
\end{tabular}

Note. $f$ stands for the frequency of the word being elicited among the associations. \% stands for the percentage of the word occurrence in relation to the total number of words

Taking into account the most frequent similarities and differences in the attributes that the teachers and the students used in their understanding of the word initiative, we get two structurally distinct but not conflicting conception of initiative. While for the teachers the term initiative denotes conscious and willing initiation of activities concretized through the creative ideas and entrepreneurial actions, for the students it denotes conscious and willing initiation of activities connected to persistence in goals attainment. More complementary than conflicting nature of differences in conceptualization of the term initiative leaves room for teacher-student joint building of the experiences of student initiative. 


\section{Manifestations of student initiative in the school environment}

The teachers and students agree on the notion that it is important for students to express initiative in school (students: $M=7.76, S D=2.39$; teachers: $M=8.07, S D=1.68$ ) and there is no statistically significant difference between their estimates $(F(1,306)=1.71, p=.192)$. However, there are differences in terms of perceptions of the expression of the students' initiative in different domains of school functioning (Figure 1). ANOVA for repeated measures (5 different domains were treated as levels of the repeated factor), revealed that the teachers assessed the expression of student initiative in these five domains differently $(F(4,181)=23.19, p<.001)$.

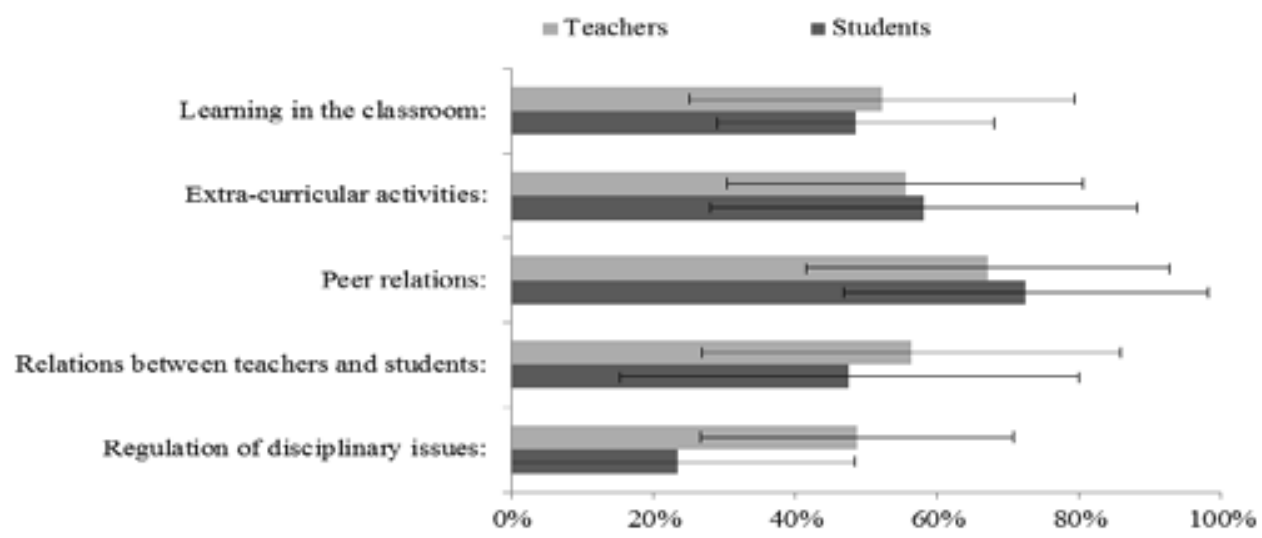

Figure 1. Teachers' and students' assessments of the manifestations of student initiative (0-100\%) in various domains of school functioning

Post-hoc tests indicated that teachers perceive that students express the most initiative when it comes to peer relationships, followed by exhibiting initiative in teacher-student relationships, extra-curricular activities and learning in the classroom. The teachers' estimates of student initiative in regulating disciplinary issues were slightly lower. The same analysis was carried out on the students' assessment, which also differed from each other $(F(4,216)=30.67, p<.001)$. Post-hoc tests showed that the students reported that their peers exhibit the most initiative in mutual relations, somewhat less within extra-curricular activities, then in learning and in interaction with teachers. The students reported on showing the least initiative in the regulation of disciplinary issues.

Compared to each other, there are significant differences in teachers' and students' assessments of: (1) student initiative in peer relations $(F(1,398)=4.14, p=.042)$; (2) student initiative in teacher-student relations $(F(1,390)=10.98, p=.001)$; (3) student initiative in regulating disciplinary issues $(F(1,390)=7.59, p=.006)$ (Figure 1$)$. The teachers believe that students express more initiative in relation to teachers and in regulating disciplinary issues than students themselves do, while the students see themselves as showing more initiative in peer relations than the teachers do. There are no differences between teachers and students when it comes to perceptions of student initiative in learning and extra-curricular activities. One can notice that significant differences are present in the assessments of the domains of school functioning that are less structured in terms of activity and in which subjective factors have an important role. 
The estimated intensity of student initiative in all five domains of school functioning (between 23\% and 72\%) leaves plenty of room for actions. Although teachers and students at least differ in regarding domains of school functioning with a clear structure and the possibility for the creation of challenging learning environment (learning in the classroom and extra-curricular activities), the estimated intensity of student initiative in this domains is between $50 \%$ and $55 \%$. At the same time, both estimate the intensity of expressing students' initiative in the field of peer relations as the domain of the greatest manifestation of student initiative (between $68 \%$ and $72 \%$ ), which could be a source of information about behavioral modalities of expressing initiative and opportunity to "implement" some of these modalities in the domain of learning in the classroom.

\section{Profile of the most initiative student}

When describing the most initiative student in the school environment, the teachers chose students who attained slightly better academic results than the individuals chosen by the student sample $(F(1,246)=35.11, p<.001)$. The average achievement of the students showing the most initiative as chosen by the student sample was $M=4.66(S D=0.54)$, whereas the teachers almost exclusively described the students with the best academic results ( $M=4.94, S D=0.30 ; 5$ is the highest mark in Serbian elementary education). When it comes to mean age of the most initiative student, the students described their peers $(M=13.91$ years, $S D=0.69)$, whereas subject teachers described students from different age groups, on average slightly younger than those described by the students $(M=13.33$ years, $S D=1.79)(F(1,347)=18.13, p<.001)$. Considering gender, there are no differences between teachers and students $(X 2=0.15, V=.02, p=.70)$. Both students $(x 2=3.22, p=.07)$ and teachers $(x 2=1.18, p=.28)$ describe boys and girls with equal frequency as the most initiative ones in the school environment.

Table 3. Personal characteristics of the most initiative student

\begin{tabular}{|c|c|c|c|c|c|c|}
\hline \multicolumn{7}{|c|}{ Personal characteristics of the of the most initiative student } \\
\hline & \multicolumn{3}{|c|}{ Teachers } & \multicolumn{3}{|c|}{ Students } \\
\hline & Student characteristics & f & $\%$ & Student characteristics & $f$ & $\%$ \\
\hline 1 & Industrious & 124 & $22.50 \%$ & Clever & 69 & $12,28 \%$ \\
\hline 2 & Curious & 65 & $11.80 \%$ & Good person/friend & 46 & $8,18 \%$ \\
\hline 3 & Communicative & 53 & $9.62 \%$ & Industrious & 33 & $5,87 \%$ \\
\hline 4 & Sociable & 38 & $6.90 \%$ & Sociable & 33 & $5,87 \%$ \\
\hline 5 & Clever & 36 & $6.53 \%$ & Witty & 28 & $4,98 \%$ \\
\hline & Other & 235 & $42.65 \%$ & Other & 353 & $62.82 \%$ \\
\hline & Total & 551 & $100 \%$ & Total & 562 & $100 \%$ \\
\hline
\end{tabular}


When describing personal characteristics of the students showing the most initiative in the school environment, the number of words/phrases used by the teachers and students is similar (551 to 562). The frequency distribution of the five words/phrases teachers and students used most often to describe the students showing the most initiative in the school environment are presented in Table 3. The descriptors presented in this table represent $57.35 \%$ of the total of the descriptors given by the teachers and $37.18 \%$ of the descriptor given by the students.

The common semantic core in five most frequent characteristics in the teachers' and students' descriptions (present in different order in $35.75 \%$ of teachers' and in $24.02 \%$ of students' descriptions) consists of the terms industrious, clever and sociable. In addition to this "core" words/phrases, the teachers' descriptions included cognitive-social characteristics (curious, communicative), while the students' descriptions included socio-emotional characteristics (good friend, witty).

Table 4. Behaviors of the most initiative student

Behaviors of the most initiative student in the school environment

Teachers

Students

\begin{tabular}{|c|c|c|c|c|c|c|}
\hline & Behaviors & $f$ & $\%$ & Behaviors & $f$ & $\%$ \\
\hline 1 & Stimulates others to action & 45 & $18.67 \%$ & Always ready to help & 45 & $18 \%$ \\
\hline 2 & Likes to cooperate & 37 & $15.35 \%$ & Behaves in a friendly way & 25 & $10 \%$ \\
\hline 3 & Has broad interest & 25 & $10.37 \%$ & Well-spoken & 23 & $9.2 \%$ \\
\hline 4 & Puts forward his own attitudes & 22 & $9.13 \%$ & Likes to joke & 12 & $4.8 \%$ \\
\hline \multirow[t]{3}{*}{5} & Expresses his own opinion & 19 & $7.88 \%$ & Likes to socialize & 12 & $4.8 \%$ \\
\hline & Other & 93 & $38.6 \%$ & Other & 133 & $53.2 \%$ \\
\hline & Total & 241 & $100 \%$ & Total & 250 & $100 \%$ \\
\hline
\end{tabular}

The total number of words/phrases by which the teachers and students described general behavior of the student showing initiative in the school environment is approximately the same (241 to 250 ). The five words/phrases (Table 4) used most frequently by the teachers to describe the behavior of the student showing initiative in the school environment comprise $61.41 \%$ of the attributes listed by this sample; five attributes most frequently used by the students make up $46.8 \%$ of all student descriptions. Comparison of the most frequent behavioral words/phrases given by the teachers and students indicates that teachers' highlight attributes which reveal self-awareness and self-presentation, whereas attributes which underline sociability prevail in the students' responses. However, despite of the use of different groups of words/phrases in these two subsamples, common ground can be found in their descriptions - it is the pro-social orientation in the behavior of the initiative student. 


\section{Discussion}

Advocates of the approach that stress the importance of development of student initiative from elementary school and beyond, emphasize that such development is the way of empowerment of young people for life in modern society, and a way for reconstruction of the active teacher-receptive student pattern of communication in school.

In accordance to our first research question findings based on the data analysis of semantic word association task indicate that both teachers and students attach numerous and various diverse meanings to term initiative. This finding problematized the issue of recognizing initiative behavior in individual and dyadic-communication levels. However, when restricting the analysis to the structure of the ten most frequently associated words in both groups we come to considerable overlapping - central to both teachers and students are words that suggest conscious and willing initiation of activity motivated by the idea or the incentive. What is different is that the initiative as a consciously and willingly started activity the teachers associate with enterprise and creativity while the students associate it with goals and success. This finding indicates that term initiative in teachers' and students' implicit cognition contains more than the colloquial meaning. Complementarity of these additional meanings could be the opportunity for teacher - student joint work on expanding understanding of the concept initiative.

In relation to our second and third research question, similar to findings in literature, we found that both teachers and students consider student initiative as an important feature in school functioning, mostly expressed in the domains of school functioning that are characterized with a small amount of structure and with openness for subjective imports (initiative in peer relationships, in extra-curricular activities and in teacher-student relationships). In addition, the findings of our study indicate that both teachers and students are similar in estimation of modest-to-low level of expression of student initiative in the classroom. In this regard, it could be hypothesized (as a goal for some future study) that specifications of different modalities of expressing student initiatives in "favorable" domains of peer relations and extracurricular activities can inspire change in teacher's classroom practices (classroom climate that balances structure and openness to students' imports; ways of encouraging student expression of initiative in the process of learning).

Although teachers and students use different phrases to describe personal characteristics and behaviours of students showing initiative, generally speaking the common component in their descriptions is prosocial orientation. Moreover, the teachers highlight attributes which reveal self-awareness and self-presentation, whereas attributes which underline sociability prevail in the students' descriptions. Looking at the bigger picture, the reported result indicates that both teachers and students describe the student showing initiative as a person who sees the school environment as a field for action and self-realization. While the teachers' descriptions of students showing initiative are similar to the characteristics denoted in the literature as 'academic initiative' (Stevens \& Miretzky, 2012), the students' descriptions are closer to what is denoted as 'development of the capacity for initiative' (Danielsen et al., 2010; Larson, 2000). This difference may be linked to two different perspectives in relating to students' development: role perspective of teachers' 
(education as main line of development); students' perspective grounded in personal experience of development.

Implications for school practice. The findings of our study show that, in the case of Serbia, the concept student initiative is not familiar enough either to teachers or to students. In this regard, an important first step in improving the practice would be work on broadening and clarifying teachers understanding of the concept of student initiative in order to enable them to more precisely recognize and support behavior indicating initiative. Also, important aspects for supporting the development of student initiative are the teachers' effort to create classroom environment that is more open for students' imports (questions, ideas, plans and projects concerning learning materials), and modalities of teacher-student conversational activities that invite students to: ask different types of questions, to evaluate answers to these questions, to raise issues about challenging parts of a teaching material, and so on. In addition, the teacher's classroom practice could be enriched with the implementation of behavioral modalities of student initiative recognized in the domain of peer relationships.

Studying the phenomenon of student initiative is a relatively new research area. In our study "giving voice" to students even when it comes to completely new issues, gave an incentivizing result. Also, the use of language that reflects everyday experience of teachers and students is a useful means for an initial consideration of the concept, but also a means to create a basis for subsequent research (questionnaire based on associations and descriptions of students and teachers).

There are few limitations of our study. First, striving to preserve the exploratory nature of the study while including different layers of participants' cognition and experiences concerning student initiative led us to pose some questions in the manner that invites to varying general assessments. Second, certain disproportion between the simplicity of tasks/questions presented in research instruments and the complexity of the process of data analysis limited the interpretation of the results. Nevertheless, we believe that the results of this study have a potential to inspire both practitioners and researchers.

\section{Conclusion}

The concept student initiative is new in understanding students' school functioning in Serbia. The findings of our study indicate that both teachers and students attach numerous and various diverse meanings to the term initiative, which problematize issue of recognition of student initiative at individual and dyadic-communication levels. However, we found that both teachers and students consider student initiative as an important feature of the student's functioning in school, mostly exspressed in peer relationships, in extra-curricular activities and in teacher-student relationships, and insufficiently expressed in classroom activities. Although both teachers and students describe the student showing initiative as a person who sees the school environment as a field for action and self-realization, the teachers emphasize attributes which reveal self-awareness and self-presentation, whereas attributes which underline sociability prevail in the students' descriptions. 


\section{References}

Appleton, J. J., Christenson, S. L. \& Furlong, M. J. (2008). Student Engagement with School: Critical Conceptual and Methodological Issues of the Construct. Psychology in the Schools, Vol. 45, No. 5, 369-386.

Axelson, R. D. \& Flick, A. (2010). Defining Student Engagement. Change: The Magazine of Higher Learning, Vol. 43, No. 1, 38-43.

Christensen, L. J. \& Menzel, K. E. (1998). The Linear Relationship between Student Reports of Teacher Immediacy Behaviors and Perceptions of State Motivation, and of Cognitive, Affective, and Behavioral Learning. Communication Education, Vol. 47, No.1, 82-90.

Danielsen, A. G.,Wiium, N., Wilhelmsen, B.U.\&Wold, B. (2010). Perceived Support Provided by Teachers and Classmates and Students' Self-Reported Academic Initiative. Journal of School Psychology, Vol. 48, No. 3, 247-267.

De Deyna, S., Pirsman,Y. \& Storms, G. (2009). Sources of Semantic Similarity. In Taatgen, N. \& H. van Rijn (Eds.), Proceedings of 31.st Annual Conference of the Cognitive Science Society (pp. 1834-1839). Amsterdam: Vrije Universiteit.

Forman, J. \& Damschroder, L. (2008). Qualitative Content Analysis. Empirical Methods for Bioethics: A Primer Advances in Bioethics, Vol. 11, 39-62.

Fredricks, J. A., Blumenfeld, P. C. \& Paris, A. H. (2004). School Engagement: Potential of the Concept, State of the Evidence. Review of Educational Research, Vol. 74, No. 1, 59-109.

Halász, G. \& Michel, A. (2011). Key Competencies in Europe: Interpretation, Policy Formulation and Implementation. European Journal of Education, Vol. 46, No. 3, 289-306.

Hargreaves, A. (2000). Mixed Emotions: Teachers' Perceptions of Their Interactions with Students. Teaching and Teacher Education, Vol.16, No. 8, 811-826.

Hattie, J. \& Timperley, H. (2007). The Power of Feedback. Review of Educational Research, Vol. 77, No. 1, 81-112.

Komlenović, Đ. i Polovina, N. (2012). Procena nastavnika o ispoljavanju učeničke inicijativnosti. Zbornik Instituta za pedagoška istraživanja, god. 44, br. 2, 266-283.

Larson, R. W. (2000). Toward a Psychology of Positive Youth Development. American Psychologist, Vol. 55, No. 1, $170-183$.

Lewis, S., Lee, O., Santau, A. \& Cone, N. (2010). Student Initiatives in Urban Elementary Science Classrooms. School Science and Mathematics, Vol. 110, No. 3, 160-172.

Llorent, V. J. (2012). Curricular Innovations for a Proactive Education - Social Development from an Individual Initiative. Procedia-Social and Behavioral Sciences, Vol. 46, 3619-3623.

Michel, A. \&Tiana, A. (2011). Editorial. European Journal of Education, Vol. 46, No. 3, 285-288.

Nelson, D. L., McEvoy, C. L. \& Dennis, S. (2000). What is Free Association and What Does It Measure? Memory \& Cognition, Vol. 28, No. 6, 887-899.

Peterman, N. E. \& Kennedy, J. (2003). Enterprise Education: Influencing Students' Perceptions of Entrepreneurship. Entrepreneurship Theory and Practice, Vol. 28, No. 2, 129-144.

Polovina, N. (2014). Inicijativnost učenika: konceptualna analiza. Zbornik Instituta za pedagoška istraživanja, god. 46, br. 2, 320-338. 
Robitschek, C. (1998). Personal Growth Initiative: The Construct and Its Measure. Measurement and Evaluation in Counseling and Development, Vol. 30, No. 4, 183-198.

Robitschek, C. \& Cook, S. W. (1999). The Influence of Personal Growth Initiative and Coping Styles on Career Exploration and Vocational Identity. Journal of Vocational Behavior, Vol. 54, No. 1, 127-141.

Stevens, S. \& Miretzky, D. (2012). Faculty's Perceptions of Students' Characteristics: A for Effort Please. Current Issues in Education, Vol.15, No. 2, Retrieved March 10, 2014 from the World Wide Web http://cie.asu.edu/ojs/index.php/cieatasu/article/view/875

Urdan, T. \& Schoenfelder, E. (2006). Classroom Effects on Student Motivation: Goal Structures, Social Relationships, and Competence Beliefs. Journal of School Psychology, Vol. 44, No. 5, 331-349.

Vujanić, M., Gortan Premk, D., Dešić, M., Dragičević, R., Nikolić. M., Nogo. Lj., Pavković, V., Ramić. N., Stijović, R., Radović Tešić, M. i Fekete, E. (2011). Rečnik Srpskog jezika. Novi Sad: Matica srpska.

Wade, R. C. (1995). Encouraging Student Initiative in a Fourth-Grade Classroom. The Elementary School Journal, Vol. 95, No. 4, 339-354.

Weber, L. \& Mayer, K. J. (2011). Designing Effective Contracts: Exploring the Influence of Framing and Expectations. Academy of Management Review, Vol. 36, No. 1, 53-75.

Witt, P. L. \& Wheeless, L. R. (2001). An Experimental Study of Teachers' Verbal and Nonverbal Immediacy and Students' Affective and Cognitive Learning. Communication Education, Vol. 50, No. 4, 327-342.

Zortea, M. \& de Salles, J. F. (2012). Semantic Word Association: Comparative Data for Brazilian Children and Adults. Psychology \& Neuroscience, Vol. 5, No.1, 77-81.

Примљено: 02. 07.2015.

Прихваћено за штампу: 05. 11. 2015. 


\title{
ИНИЦИЈАТИВНОСТ УЧЕНИКА КАКО ЈЕ ПОИМАЈУ И ПРОЦЕЊУЈУ НАСТАВНИЦИ И УЧЕНИЦИ ОСНОВНИХ ШКОЛА
}

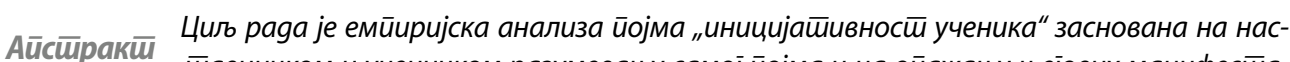

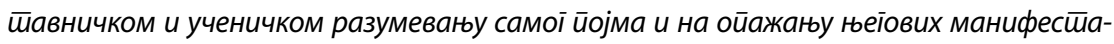

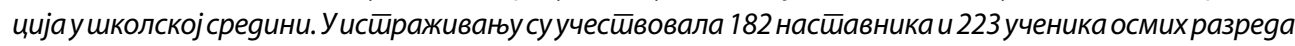

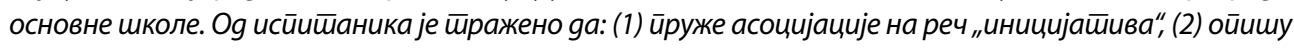
личне особине и йонашањ ученика који исйољавају највише иницијайиве; (3) gају йрочене значаја и

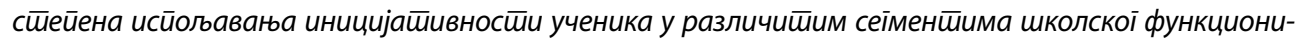

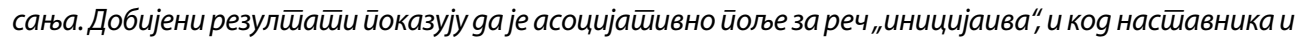
коg ученика, изузеш̄но велико и са малом асоцијайивном снаїом шйо указује на више разноликих

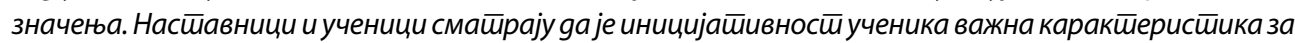

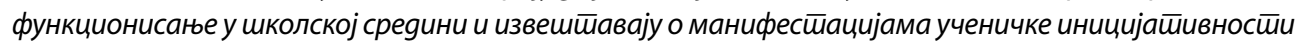

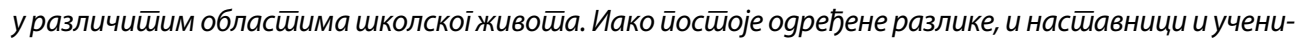

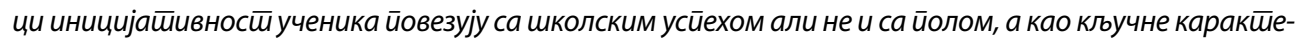

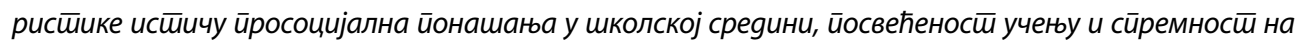
gоgайно анїажовање на часу. На крају раgа указано је на имйликације за школску ӣраксу, у смислу

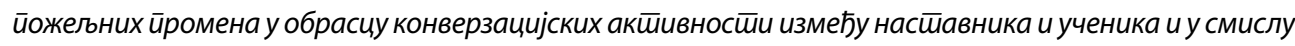
увођена сложених и изазовних заgайака везаних за насйавне саgжаје.
\end{abstract}

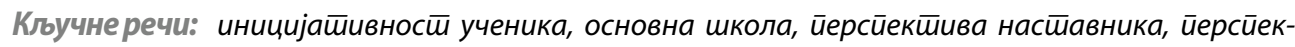

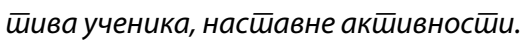

\section{ИНИЦИАТИВНОСТЬ УЧЕНИКОВ ПОНИМАЕМАЯ И РАСЦЕНИВАЕМАЯ УЧИТЕЛЯМИ И УЧЕНИКАМИ ОСНОВНЫХ ШКОЛ}

\begin{abstract}
Резюме В статье приводятся результаты эмпирического анализа понятия „инициативность учеников" на основе того, как данное понятие понимают учителя и ученики и как они относятся к проявлению инициативности в школьной среде. Исследование проведено на примере 182 учителей и 223 учеников восьмого класса восьмилетней школы. Респондентам было предложено: (1) привести ассоциачи со словом „инициатива”, (2) описать личностные характеристики и поведение учеников, которые часто проявляют инициативу, (3) дать оценку значения и уровня проявления инициативы учеников в различных сегментах функционирования школы. Результаты показывают, что ассоциативное поле слова „инициатива" и у учителей и у учеников очень большое и обладает небольшой ассоциативной силой, что указывает на больше разнообразных значений. Учителя и ученики считают, что инициативность ученика является важной характеристикой его функционирования в школьной среде. Они сообщают о способах проявления инициативы в различных областях школьной жизни. Хотя существуют некоторые различия между ними, однако и учителя и ученики инициативность учеников связывают с школьным успехом, а в качестве ключевых особенностей приводят просочиальное поведение в школьной среде, стремление кучебе и готовность к дополнительной работе на уроках. В конце статьи указывается на возможность практического применения результатов исследования путем введения творческих, интересных и комплексных заданий в процесс обучения.
\end{abstract}

Ключевые слова: Ключевые слова: инициативность ученика, восьмилетняя школа, мнения учителей, мнения учеников, педагогические активности. 